\title{
Aves, Apodidae, Cypseloides senex (Temminck, 1826): Geographical distribution in the state of Rio Grande do Sul, southern Brazil
}

\author{
Samuel Lopes Oliveira \\ Programa de Pós-Graduação em Ecologia e Conservação, Universidade Federal do Paraná. CEP 81531-980. Curitiba, PR, Brasil. \\ E-mail: samuel.lo@ufpr.com
}

\begin{abstract}
The Great Dusky Swift Cypseloides senex occurs mainly in Argentina, Bolivia and Brazil. Little is known about the status of this species in the state of Rio Grande do Sul, Brazil. To fill this gap, several ornithologists and museum collections were consulted for records. This paper presents records for nine new localities in the state of Rio Grande do Sul. Cypseloides senex occurs along the central and northeast portions of the Planalto escarpment and the upper valley of the Uruguay River.
\end{abstract}

The Great Dusky Swift Cypseloides senex (Temminck, 1826) is the largest species of the genus found in Brazil; it feeds mainly on insects which are caught in flight over forests (Sick 1997). This gregarious species is strongly associated to waterfalls, where it nests usually atop of a cleft in the rock, using mosses and liverworts bounded together with saliva to build its nests (Sick 1997; Chantler 1999). It occurs mainly in Argentina, Brazil and Bolivia, and more rarely in Peru and Paraguay. In Brazil it occurs from Pará, in the north, to Rio Grande do Sul, in the south (Stotz et al. 1996; Sick 1997; Chantler 1999; Piacentini et al. 2006; Accordi and Barcelos 2008).

In the state of Rio Grande do Sul, the species was not included in the list published by Belton (1994), being first mentioned by Bencke (2001), but with no details regarding the record. Later, $C$. senex was mentioned for São Francisco de Paula, on the northeast portion of the Planalto escarpment (Barnett et al. 2004), this being the only published record for the state with a specific locality. The observations of $C$. senex in Rio Grande do Sul are recent and these extra-limital records could relate to recent range expansion or the discovery of previously undocumented populations, termed "range extension". In order to distinguish range expansion from extension, Frey (2009) proposed the use of background data, which are records of a similar species other than the taxon of interest that are likely to be documented using the same sampling method. This paper aims to improve the knowledge on the distribution of $C$. senex in Rio Grande do Sul, providing data that help to understand the status of the species in the state. Moreover, the pattern of the distributional range of $C$. senex in the state is discussed, and background data is used in order to attempt to distinguish range expansion from range extension.

Data were obtained consulting ornithologists and museum collections. National museums were consulted through the curators and international museums were consulted by the online database (Museu de Ciências Naturais da Fundação Zoobotânica do Rio Grande do Sul, Porto Alegre, Brazil, on 29 January 2010; Museu de História Natural Capão da Imbuia, Curitiba, Brazil, on 21 March 2011; Museu de Zoologia da Universidade de São Paulo, São Paulo, Brazil, on 08 March 2011; Museu Paraense Emílio Goeldi, Belém, Brazil, on 10 March 2011; Smithsonian Institution, Washington, USA, on 12 March 2011; and Field Museum of Natural History, Chicago, USA, on 12 March 2011). This information, plus a personal record and one previously published record were used to create a distribution map of $S$. senex in Rio Grande do Sul.

Nine new localities with records of $C$. senex in Rio Grande do Sul state were identified (Figure 1). Below are the details of the records.

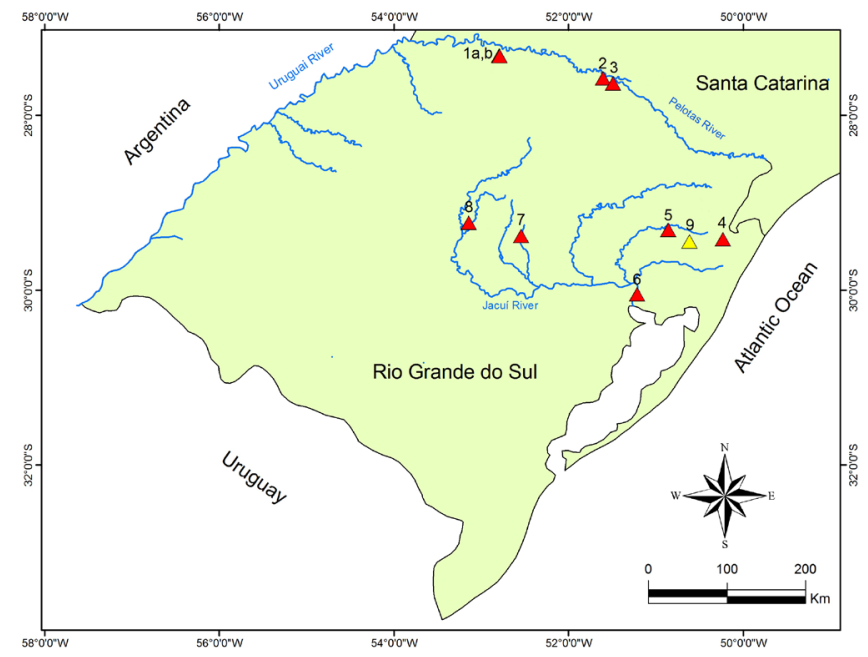

FIGURE 1. Geographic distribution of Cypseloides senex in Rio Grande do Sul state. New localities are marked by red triangles: 1a,b) Nonoai; 2) Machadinho, Linha Tigre; 3) Barracão, Cascata das Andorinhas; 4) São Francisco de Paula, Estação Ecológica Estadual de Aratinga; 5) Cascata do Caracol; 6) Porto Alegre; 7) Sinimbu, Salto do rio Pardinho; 8) Estrela Velha, Rincão do Espinilho. Previously published record is marked by yellow triangles: 9) São Francisco de Paula, near Veraneio Hampel Hotel. 
1a) Nonoai (2718’58” S, 5247'24" W; 550 m a.s.l.). 26 July 2009. Glayson Ariel Bencke recorded a flock of ten birds flying over a remnant of Araucaria forest. 1b) Later the same day, he also observed a single individual flying over crops in a place $840 \mathrm{~m}$ far from the latter fragment (2719'24" S, 52 $47^{\prime} 16^{\prime \prime} \mathrm{W}$; $600 \mathrm{~m}$ a.s.l.).

2) Linha Tigre $\left(27^{\circ} 34^{\prime} 31^{\prime \prime} \mathrm{S}, 5^{\circ} 36^{\prime} 15^{\prime \prime} \mathrm{W} ; 611 \mathrm{~m}\right.$ a.s.l.), municipality of Machadinho. 18 December 2001. A female with moderately developed ovaries (MCN 2731) collected by André Alberto Witt in a waterfall and deposited in the Museu de Ciências Naturais (MCN) da Fundação Zoobotânica do Rio Grande do Sul.

3) Cascata das Andorinhas (273' $15^{\prime \prime} \mathrm{S}, 5^{\circ} 29^{\prime} 17^{\prime \prime} \mathrm{W}$; 585 m a.s.l.), municipality of Barracão. 17 November 2009. Fábio Silveira Vilella observed a population of about 200 individuals in a waterfall in the Marmeleiro River (Figure 2). The name of the waterfall is translated to English as Swallow's Waterfall. Considering that, local residents do not distinguish swallows from swifts, this designation could refer to a breeding population in this waterfall.

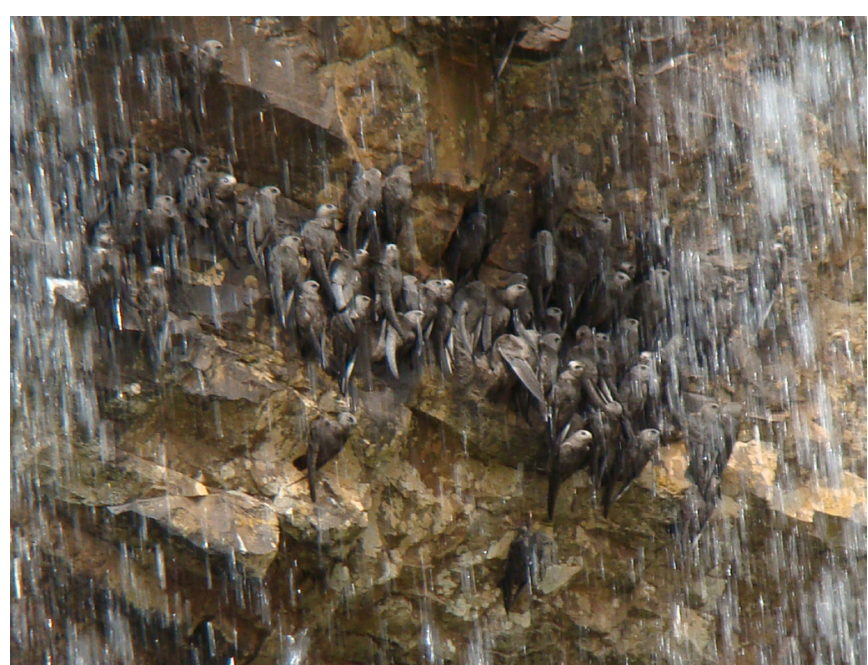

FIgurE 2. Cypseloides senex recorded at Cascata das Andorinhas, Barracão municipality. Photo by F.S. Vilella, 2009.

4) Estação Ecológica Estadual de Aratinga (29²1'33" S, 50¹1'43" W; 850 m a.s.l.), municipality of São Francisco de Paula. 29 November 2008. Bret M. Whitney and G.A.B. recorded a mixed flock of 15-20 individuals of $C$. senex and 5-8 individuals of Streptoprocne zonaris (Shaw, 1796) flying over second-growth forest, fields and pine plantation on the edge of the forested valley of the Carvalho creek. There are at least three big waterfalls in the vicinity where the birds could find shelter.

5) Cascata do Caracol (29¹8'40” S, 5051'20” W; 660 $m$ a.s.l.), municipality of Canela. Records collected by Daniel Schlieper began in October 1996 (Figure 3), and monitoring of this population continued until 2006. In this location, $C$. senex is resident and nests between October and January. According to D. Schlieper (pers. com.), during a search, 42 nests were found at levels where the water formed a curtain. The nests were made of moss and mud, each containing only one egg.

6) Bairro da Azenha (3002'51" S, 51²12'49" W; 10 $\mathrm{m}$ a.s.l.), Porto Alegre city, municipality of Porto Alegre. 12 February 1998. Skin (MCN 2715) deposited in the Museu de Ciências Naturais (MCN) of the Fundação

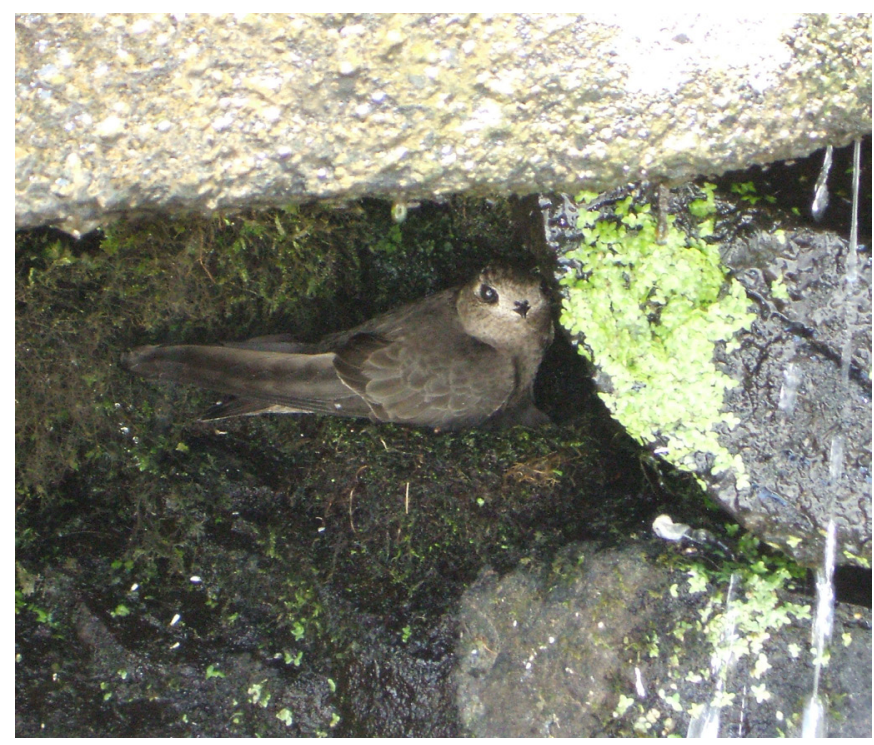

FigurE 3. Cypseloides senex recorded at a nest in Cascata do Caracol, Canela municipality. Photo by D. Schlieper, 2007.

Zoobotânica do Rio Grande do Sul, collected by Eduardo Pires de Albuquerque. This specimen was found alive on the street and taken to the museum, where a fracture in the skull was detected during the skin preparation (E. P. Albuquerque pers. com.). Probably the individual collided with a building.

7) Salto do Rio Pardinho (29²2'55” S, 52³2'33" W; 265 m a.s.l.), municipality of Sinimbu. 26 February 2000. Gilmar Klein recorded about 50 individuals in a waterfall in the Pardinho River.

8) Rincão do Espinilho (29¹3'43" S, 5308'22" W; 270 m a.s.l.), municipality of Estrela Velha. 31 December 2008. Record obtained by the author, accompanied by Rafael Barbizan Sühs, Alexandre Somavilla and Fernanda Zenkner. Twenty individuals were sighted, some foraging over the forest while others were resting on the cliffs of the Cascata do Espinilho.

There is one previously published record of $C$. senex. This was used in addition to the new records described above to create a distribution map for the species in Rio Grande do Sul (Figure 1). Details of this record are presented below.

9) Near the Veraneio Hampel Hotel (29²6’34" S, 50³6'40" W; 885 m a.s.l.), municipality of São Francisco de Paula. 26 November 2002. Guy M. Kirwan observed for several minutes one individual of $C$. senex in a flock of about 30 individuals of Streptoprocne sp. (Sclater, 1866) (Barnett et al. 2004).

Considering the available records (Figure 1), the distribution of $C$. senex in Rio Grande do Sul covers the northern half of the state, following the limits of the Atlantic Forest in the central and northeastern Planalto escarpment, and the valley of the upper Uruguay River in the north. For the latter there is also one record in the state of Santa Catarina on the border of Rio Grande do Sul (Accordi and Barcelos 2008). Except for the Porto Alegre record, all the other records were in regions with the presence of deep valleys and rivers, where cliffs and waterfalls are known or likely to occur. Since the Porto Alegre area is not suitable for the species in terms of habitat, this locality probably does not harbor a population of $C$. senex. 
Evaluating available background data (Bencke 1996; Bencke and Kindel 1999; Scherer et al. 2005; Accordi and Barcelos 2006; Silva 2006; Santos and Cademartori 2007; Teixeira et al. 2009; Oliveira and Köhler 2010; Santos and Petry 2010) and considering Cypseloides fumigatus (Streubel, 1848) as a similar species likely to be recorded, it is possible to claim that $C$. senex could have been recorded if already present in the state. Nevertheless, this species is not easily sampled or collected and should be considered the difficulty to separate $C$. senex and $C$. fumigatus in the field. According to G. A. Bencke (pers. com.), perched $C$. senex appears to have the head lighter than the body, but in flying birds this feature is usually hard to notice. Thus, some authors could have been wrong in the identification. For instance, William Belton had visited and lived close to the Cascata do Caracol. However, he observed only C. fumigatus in the waterfall (Belton 1994). During ten years of work in the locality, D. Schlieper (pers. com.) did not recorded $C$. fumigatus breeding or roosting in the waterfall. This means that $\mathrm{W}$. Belton could have been wrong or $C$. senex colonized this area later. The lack of data makes impossible to analyze this issue and conclude for extension or range expansion.

Concerning the conservation of $C$. senex in Rio Grande do Sul, the greatest threat the species faces is the building of dams. These may affect breeding and roosting populations by flooding waterfalls (Stotz et al. 1996; Chantler 1999). Breeding populations that could exist in the valley of the Uruguay River may have been extinct or reduced by the recent construction of four large dams on the upper reaches of the river. The paucity of data about the biology and distribution of $C$. Senex, in all its range area, makes it a species of high research priority (Stotz et al. 1996). Thereby, further studies are recommended in order to find new areas where $C$. senex breeds to determine whether these populations face any imminent threat, as well as to understand better the niche of the species and its behavior in the southern limit of its distribution.

ACKNOWLEDGMENTS: I thank Glayson Ariel Bencke for providing two records and helping with the discussion. Also thank Bret Whitney, Fábio Silveira Vilella, Iury de Almeida Accordi, Daniel Schlieper, Gilmar Klein, Eduardo Pires de Albuquerque, Rafael Barbizan Sühs, Alexandre Somavilla and Fernanda Zenkner, who provided the records and authorized their use in this work. Daniel Schlieper and Fábio Silveira Vilella provided the photographs. Museum curators Alexandre Aleixo, Luis Fábio Silveira, Glayson Ariel Bencke and Antenor Silva Júnior. And the four referees that made valuable comments on the manuscript.

\section{Literature Cited}

Accordi, I.A. and A. Barcelos. 2006. Composição da avifauna em oito áreas úmidas da Bacia Hidrográfica do Lago Guaíba, Rio Grande do Sul. Revista Brasileira de Ornitologia 14(2): 101-115.

Accordi, I.A. and A. Barcelos. 2008. Novas ocorrências e registros notáveis sobre distribuição de aves em Santa Catarina, sul do Brasil. Biotemas 21(1): 85-93.

Barnett, J.M., J. Minns, G.M. Kirwan and H. Remold. 2004. Informações adicionais sobre as aves dos estados do Paraná, Santa Catarina e Rio Grande do Sul. Ararajuba 12(1): 53-56.

Belton, W. 1994. Aves do Rio Grande do Sul: distribuição e biologia. São Leopoldo: Unisinos. 584 p.

Bencke, G.A. 1996. Annotated list of birds of Monte Alverne, Central Rio Grande do Sul. Acta Biologica Leopoldensia 18: 17-42.

Bencke, G.A. and A. Kindel. 1999. Bird counts along an altitudinal gradient of Atlantic forest in northeastern Rio Grande do Sul, Brazil. Ararajuba 7(2): 91-107.

Bencke, G.A. 2001. Lista de referência das aves do Rio Grande do Sul. Porto Alegre: Fundação Zoobotânica do Rio Grande do Sul. Publicações Avulsas FZB. 104 p.

Chantler, P.1999. Family Apodidae (Swifts); p. 388-457 In J. del Hoyo, A. Elliot and J. Sartagal (ed.). Handbook of the Birds of the World, Vol. 5. Barn-owls to hummingbirds. Barcelona: Lynx Ediciones.

Frey, J.K. 2009. Distinguishing range expansion from previously undocumented populations using background data from museum records. Diversity and Distributions 15(2): 183-187.

Lomolino, M.V., B.R. Riddle and J.H. Brown. 2006. Biogeography. Sunderland: Sinauer Associates. 845 p.

Oliveira, S.L. and A. Köhler. 2010. Avifauna da RPPN da UNISC, Sinimbu, Rio Grande do Sul, Brasil. Biotemas 23(3): 93-103.

Piacentini, V.Q., I.R. Ghizoni-JR, M.A.G. Azevedo and G.M. Kirwan. 2006 Sobre a distribuição de aves em Santa Catarina, Brasil, parte I: registros relevantes para o estado ou inéditos para a Ilha de Santa Catarina. Cotinga 26(1): 25-31.

Santos, M.F.B. and C.V. Cademartori. 2007. Contribuição ao conhecimento da avifauna do município de Araricá, Rio Grande do Sul. Biotemas 20(2): 41-48.

Santos, M.F.B. and M.V. Petry. 2010. Registros recentes de aves de importância conservacionista no extremo norte do Rio Grande do Sul, Brasil. Biotemas 23(1): 161-168.

Scherer, A., S.B. Scherer, L. Bugoni, L.V. Mohr, M.A. Efe and S.M. Hartz. 2005. Estrutúra trófica da avifauna em oito parques da cidade de Porto Alegre, Rio Grande do Sul, Brasil. Ornithologia 1(1): 25-32.

Sick, H. 1997. Ornitologia brasileira. Rio de Janeiro: Nova Fronteira. 862 p.

Silva, R.R.V. 2006. Estrutura de uma comunidade de aves em Caxias do Sul, Rio Grande do Sul, Brasil. Biociências 14(1): 27-36.

Stotz, D.F., J.W. Fitzpatrick, T.A. Parker III and D.K. Moskovits. 1996. Neotropical birds: ecology and conservation. Chicago: University of Chicago Press. 478 p.

Teixeira, E.M., I.P. Bernardi and F.A.F. Jacomassa. 2009. Avifauna de Frederico Westphalen, Rio Grande do Sul, Brasil. Biotemas 22(4): 117-124.

RECEIVED: January 2011

LAST REVISED: March 2011

ACCEPTED: June 2011

Published ONLINE: July 2011

EDITORIAL RESPONSIBILITY: Dárius P. Tubelis 